\title{
Profile of women affected with premature childbirth and neonatal outcomes
}

\section{Mateus Moura da Silva 1}

iD https://orcid.org/0000-0003-2874-8195

Angelita Lívia da Silveira Brito 2

iD https://orcid.org/0000-0001-7968-6014

Ismaelle Ávila Vasconcelos 3

(iD) https://orcid.org/0000-0002-2416-8524

Raissa Emanuelle Medeiros Souto 4

iD https://orcid.org/0000-0001-5995-2784

Ryvanne Paulino Rocha 5

iD https://orcid.org/0000-0002-6720-6076
Cinthia Maria Gomes da Costa Escoto Esteche 6

(iD https://orcid.org/0000-0001-6958-3185

Ana Kelve de Castro Damasceno 7

(iD) https://orcid.org/0000-0003-4690-9327

Jamile Lopes de Moraes 8

(iD) https://orcid.org/0000-0003-1861-0790

Maria Roselise Bezerra Saraiva 9

iD https://orcid.org/0000-0003-4874-9013

1-3 Centro de Ciências. Universidade Federal do Ceará. Rua Alexandre Baraúna, 1115. Rodolfo Teófilo. Fortaleza, CE, Brasil. CEP: 60.455-760. E-mail: mateusmourah@hotmail.com

4-7 Departamento de Enfermagem. Universidade Federal do Ceará. Fortaleza, CE, Brasil.

8.9 Maternidade Escola Assis Chateaubriand. Fortaleza, CE, Brasil.

\begin{abstract}
Objectives: to describe the profile of women affected with premature childbirth and neonatal outcomes at a referral maternity in the city of Fortaleza-CE, Brazil.

Methods: descriptive and retrospective documentary type study, with a quantitative approach, carried out from January to December, 2017, with 253 medical records of women who had premature childbirth in a referral maternity.

Results: the average age was 28 , with the prevalence of women living in a stable union, graduated from high school and without formal work. The gestational mean average was three pregnancies, gestational age of 34 weeks and three days, and six prenatal consultations, starting in the first trimester. The major intercurrence was pre-eclampsia. In relation to the neonatal data, there was a prevalence of male newborns, with an average of $2.251 \mathrm{~kg}$ and a score of seven on the 1-minute Apgar and eight on the 5-minute Apgar. Newborns in going to a hospital accommodation after childbirth and in room air, spending an average of 12.71 days in the hospital.

Conclusion: in this case of this research, knowing the woman's profile and the outcomes in premature newborns is useful to encourage public policies and reduce the sequelae on mother and baby
\end{abstract}

Key words Premature, Labor, Risk factors

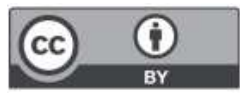




\section{Introduction}

Prematurity is the main condition associated with neonatal and infant mortality, with an increase in cases worldwide. In Brazil, the national rate of prematurity increased from $9.8 \%$ in 2011 , to $11.86 \%$ in 2012 , being among the top 10 countries with the most premature births, at around 280 thousand preterm childbirths in the country, becoming even more significant when it is known that $70 \%$ of preterm infants die within 28 days of life. 1,2

Infant mortality corresponds to the child's death in the first year of life, either in the neonatal period, which corresponds to death occurring between zero and 27 days of life, or the postnatal period, with death occurring between 28 and 364 days of life. 3

The main component of infant mortality is early neonatal mortality, with most deaths occurring in the first 24 hours, indicating a close relationship to childbirth and birth, prematurity being among the main causes, as well as congenital malformation, intrapartum asphyxia, perinatal infections and maternal factors. 4

Many born preterm evolve with sequelae in several systems, increasing infant morbimortality. With a premature NB, the mother faces the unexpected: dealing with a baby who may not survive or will require greater care. 5,6

Brazil managed to reduce infant mortality rates, from 51 deaths per thousand live births in 1990, to 15 per thousand live births in 2015 , but the rates remain high, with 19.88 deaths per thousand live births and neonatal mortality representing $70 \%$ of child deaths in all regions of the country. ${ }^{7}$

Also, low maternal socioeconomical level is associated with prematurity, due to malnutrition, infections and the lack of proper prenatal care, as well as smoking, drug abuse, multiple gestations and great physical and psychological stress. Pregnancy during adolescence, one of the extreme reported age group, evidences that this group has a relation with premature childbirth and low birth weight newborns, being attentive with other combined factors, such as social vulnerability, reduced access to health services, inadequate habits and nutrition, among others. 8,9

While adolescence is associated with premature childbirth, so is advanced maternal age. Due to changes in the women's lifestyle, pregnancies after 40 years old are more frequent, being associated with fetal, maternal, the newborn complications and during pregnancy and childbirth. 10

Thus, the best way to avoid or reduce mortality rates and the problems and sequelae associated with prematurity is to reduce premature births. Therefore, it is necessary to identify its main risk factors and act. The ideal time for this is prenatal care, which has been shown to be an empowering factor in reducing premature birth rates, due to the better evaluation of pregnant women and time to pass on essential information. 11,12

Based on the above, this study justifies by the need to reduce cases on premature childbirths, due to the implications related to this period of births, and to understand the risk factors that lead to this outcome, thus, being able to avoid them. Moreover, it is noted that, in the studied maternity, in 2017, there were 4,853 childbirths, out of which 1,375 $(28.3 \%)$ were premature, making the analysis of their influential factors necessary when aiming at reducing this rate.

Thus, this study seeks to answer these questions: what is the profile of women affected with premature childbirth? and what are the neonatal outcomes? As our goal is to describe the profile of women affected with premature childbirth and the neonatal outcomes in a referral maternity in the city of Fortaleza-CE, Brazil.

\section{Methods}

Descriptive, retrospective documentary study with a quantitative approach. A documental study is an empirical investigation, whose purpose is the delineation or analysis of the characteristics of facts or phenomena, the evaluation of programs, or the isolation of the main variables or keys. ${ }^{13}$

Descriptive studies consist of observing, describing and documenting aspects of a given situation. Aquantitativeresearch, which has its roots in logical positivist thinking, tends to emphasize deductive reasoning, the rules of logic, and the measurable attributes of the human experience. 14

The study was carried out at the Maternidade Escola Assis Chateaubriand (MEAC), an institution of reference in the state of Ceará, belonging to the Hospital complex of the Universidade Federal do Ceará (UFC), associated with the Sistema Único de Saúde (SUS), (Brazilian Public Health System) where activities of average and high complexity are developed, in hospital care and outpatient care for the woman and the newborn. The mission is to promote formation in human resources to promote learning, teaching, research and extension, providing service of excellence to the woman and the newborn. Data was collected from women who had NBs between January and December, 2017.

The population was comprised of women who 
had premature childbirth between the months of January and December of 2017, in the aforementioned maternity. Secondary sources were used for data collection. The inclusion criteria for this study were puerperal women whose outcome was the birth of newborns from 21 weeks to 36 weeks and six days. Women who birthed newborns with congenital malformations and those who were not possible to calculate the gestational age (lack of maternal information or neonatal deaths before the physical examination and New Ballard Score calculation) were excluded.

Considering that in 2017 there were 4,853 childbirths at the studied maternity, among vaginal and abdominal childbirths which, 1,375 were premature childbirths, 253 women were researched using the sample calculation formula for finite populations.

It was a simple random sample, where each component of the population has the same chances of being chosen to compose the study, being calculated and based on the following formula for finite populations, as previously mentioned, applying the confidence coefficient of $95 \%$, the prevalence of $28 \%$ for premature labor and maximum permissible error of $5 \%$, with a final total sample size of 253 women. The formula used for the sample calculation was 15 :

$$
\mathrm{n}=\frac{\mathrm{Z}^{2} \cdot \mathrm{p} \cdot \mathrm{q} \cdot \mathrm{N}}{\mathrm{e}^{2} \cdot(\mathrm{N}-1)+\mathrm{Z}^{2} \cdot \mathrm{p} \cdot \mathrm{q}}
$$

In which:

$\mathrm{n}=$ Size of the sample;

$\mathrm{Z}^{2}=$ Confidence coefficient;

$\mathrm{N}=$ Complementary sum;

$\mathrm{q}=$ Percentage in which the phenomenon occurs;

$\mathrm{p}=$ Percentage to the population and

$\mathrm{e}^{2}=$ Maximum permissible error.

Data collection took place between July and October 2018, data which was obtained from the women's medical records, the newborn's, the Declaração de Nascidos Vivos (Live Births Statements) and the NB's assessment form, using a previously elaborated tool.

The Formulário de Identificação do Perfil Sociodemográfico, Obstétrico e Neonatal (Sociodemographic, Obstetric and Neonatal Profile Identification Form) was used, divided into four blocks: identification data, obstetric history, pregnancy and current childbirth, and neonatal component. The study data was collected and managed using the REDCap1 electronic data collection and management tool, located at the Unidade de
Pesquisa Clínica do Complexo de Hospitais Universitários da UFC (Clinical Research Unit of the UFC University Hospitals Complex) and organized in tables. 16

The project was submitted to the Research Ethics Committee of the Maternidade Escola Assis Chateaubriand, via Plataforma Brasil, under the number 2,786,220. A Faithful Depositary term was signed, as this research is with secondary sources.

\section{Results}

In 2017 , there were 4,853 childbirths at the studied institution, among vaginal and $\mathrm{C}$-sections, of which, 1,375 were premature, corresponding to $28.3 \%$ of all childbirths at the hospital.

When evaluating the sociodemographic profile of the 253 women who had premature childbirths in 2017 in the respective maternity, it was found that, with regards to the origin of the women surveyed, $63.1 \%$ were from the capital - Fortaleza - and 36.9\% were from the countryside.

The women's minimum age presented in the study was 12 years and the maximum was 46 , with a mean of 28 years $(\mathrm{SD}=7.29)$. In regard to marital status, there were women living in a stable union, corresponding to $41.9 \%, 37.2 \%$ graduated from high school. As for occupation, $49.1 \%$ were housewives (Table 1).

In relation to obstetric history, the number of pregnancies ranged from 1 to 11 , with a gestational average of three pregnancies ( $\mathrm{SD}=1.58)$, with childbirths ranging from none to eight, with the mean of one birth $(\mathrm{SD}=1.27)$. Of them, 75 were primiparous (29.6\%) and 178 multiparous (70.4\%). Abortions varied between none and four, the mean was 0.4 abortions $(\mathrm{SD}=0.76)$.

When relating tostillbirths, it ranged from zero to two, with a mean of 0.01 stillbirths $(\mathrm{SD}=0.13)$. Regarding the number of C-sections, the occurrence varied from zero to four, with a mean of 0.43 $(\mathrm{SD}=0.78)$ and normal childbirths ranged from zero to eight, with a mean of $0.74(\mathrm{SD}=1.20)$.

In regards to the data on the current pregnancy and childbirth, the gestational age ranged from 21 to 36 gestational weeks, with a mean of 34 gestational weeks $(\mathrm{SD}=3.0)$ and, as for the days, zero to six days, with a mean of three days $(\mathrm{SD}=2.05)$, resulting in a gestational average of 34 weeks and three days. When researching how the gestational age was measured, $79.9 \%$ were performed by ultrasound (US) in the first trimester, $14.3 \%$ in the second, $2.7 \%$ in the third, $1.9 \%$ by the date of the last menstruation and $1.2 \%$ by Capurro. 


\begin{tabular}{|c|c|c|}
\hline Variables & $\mathbf{N}$ & $\%$ \\
\hline \multicolumn{3}{|l|}{ Origin } \\
\hline Capital & 159 & 63.1 \\
\hline Countryside & 93 & 36.9 \\
\hline \multicolumn{3}{|l|}{ Marital Status } \\
\hline Single & 65 & 25.7 \\
\hline Stable union & 106 & 41.9 \\
\hline Married & 81 & 32 \\
\hline Widowed & 0 & 0 \\
\hline Divorced & 1 & 0.4 \\
\hline \multicolumn{3}{|l|}{ Schooling } \\
\hline No schooling & 1 & 0.4 \\
\hline 1st to 4 th grade & 8 & 3.2 \\
\hline 5 th to 9 th grade & 73 & 28.8 \\
\hline Graduated from High School & 94 & 37.2 \\
\hline High School not concluded & 41 & 16.2 \\
\hline Graduated from Higher Education & 25 & 9.9 \\
\hline Higher Education not concluded & 11 & 4.3 \\
\hline \multicolumn{3}{|l|}{ Occupation } \\
\hline Housewife & 124 & 49.1 \\
\hline Student & 22 & 8.7 \\
\hline Farmer & 13 & 5.1 \\
\hline Teacher & 10 & 3.9 \\
\hline Others & 84 & 33.2 \\
\hline
\end{tabular}

Prenatal consultations varied between 0 and 13 consultations, with an average of six consultations $(\mathrm{SD}=1.33)$. Regarding the beginning of prenatal care, $69.7 \%$ started in the first trimester, $20.1 \%$ in the second and $0.8 \%$ in the third, while $9.4 \%$ of the medical records did not have any information on the beginning of prenatal care.

Regarding the use of tobacco, $94.9 \%$ did not smoke and $5.1 \%$ did. With regards to consuming alcohol, 95.3\% did not drink and 4.7\% drank alcohol during the pregnancy. When investigating the use of illegal drugs, $98 \%$ did not use drugs and $2 \%$ made use of some sort of illicit drug.

Regarding to intercurrence in the pregnancy, most cases were pre-eclampsia, at $42 \%$, followed by urinary tract infection in the third trimester $(24.4 \%)$, threatened preterm childbirth $(22.3 \%)$, multiple pregnancy $(11.6 \%)$, diabetes $(11.6 \%)$, first trimester bleeding (9.4\%) and intrauterine growth restriction $(1.3 \%)$. There were also other intercurrences that totaled 33\%, among which, hypothyroidism, syphilis, arboviruses, retroviruses and others (Table 2).

Previous preterm childbirths ranged from zero to four, with a mean of 0.86 , being that $85.8 \%$ were not shown in their medical records. Corticoid doses ranged from none to five, with a mean of 1.2 $(\mathrm{SD}=0.88)$, with $4.3 \%$ without any registration.

As for hospitalizations during pregnancy, $70.4 \%$ did not need to be hospitalized for any reason and $29.6 \%$ were hospitalized. When researching the reason for this hospitalization: $30.6 \%$ were for preeclampsia; $20 \%$ were due to premature rupture of ovular membranes; $13.3 \%$ were due to premature labor and $13.3 \%$ for other reasons, and $10.6 \%$ of the information was missing from the medical records.

In relation to the current type of pregnancy, $87.7 \%$ were single and $12.3 \%$ were double. The most prevalent type of childbirth was cesarean $(66.8 \%)$, followed by vaginal childbirth $(33.2 \%)$. The most prevalent indication for a $\mathrm{C}$-section was preeclampsia $(40.2 \%)$, followed by twins $(10.6 \%)$, previous C-section (8.9) and others (53.2\%).

Regarding neonatal data, $53.5 \%$ were males and $46.5 \%$ females. The weight varied between 490 grams and 3.840 kilograms, with an average of 2.251 kilograms $(\mathrm{SD}=671)$. First-minute Apgar scores ranged from 1 to 10 , with a mean of $7(\mathrm{SD}=2)$ and, 
in the fifth minute, it ranged from 3 to 10 , with a mean of $8(\mathrm{SD}=1)$.

When the fetal presentation before birth was investigated, $79.8 \%$ were cephalic, $18.5 \%$ pelvic and $1.7 \%$ transverse. Regarding cesareans occurred before labor, $62.7 \%$ were before and $37.3 \%$ after labor had already started.

When investigating to which unit the premature newborn was taken, $39.2 \%$ were sent to hospital accommodation, $31.6 \%$ went to the Intensive Care Unit, among $3 \mathrm{~A}$ and $3 \mathrm{~B}$, and $29.2 \%$ to the Unidade de Cuidados Intermediários Convencionais (UCINCO) (Conventional Intermediate Neonatal Care Unit), among UCINCO I and II. When assessing which respiratory mechanism the patient left the neonatology room with, $49.1 \%$ left in room air, $26.1 \%$ in Hood, $13.4 \%$ were intubated and $11.4 \%$ were on CPAP. Hospital leave varied between zero

Table 2

Distribution of women who had premature childbirths, according to obstetric intercurrences. Fortaleza - CE, Brazil, $2017(n=253)$

\begin{tabular}{|c|c|c|}
\hline Variables & $\mathbf{N}$ & $\%$ \\
\hline Pre-eclampsia & 94 & 42.0 \\
\hline Prior Hypertension & 23 & 10.3 \\
\hline 1st trimester urinary tract infection & 45 & 20.1 \\
\hline $2^{\text {nd }}$ trimester urinary tract infection & 36 & 16.1 \\
\hline $3^{\text {rd }}$ trimester urinary tract infection & 57 & 24.4 \\
\hline Treated urinary tract infection & 67 & 29.9 \\
\hline Untreated urinary tract infection & 32 & 14.3 \\
\hline Multiple pregnancy & 26 & 11.6 \\
\hline Threatened preterm childbirth & 50 & 22.3 \\
\hline 1st trimester bleeding & 21 & 9.4 \\
\hline 2nd trimester bleeding & 14 & 6.3 \\
\hline 3rd trimester bleeding & 16 & 7.1 \\
\hline Diabetes & 12 & 5.4 \\
\hline Diabetes using insulin & 9 & 4.0 \\
\hline Diabetes using hypoglycemic & 5 & 2.2 \\
\hline Intrauterine growth restriction & 8 & 1.3 \\
\hline Cardiopathy & 2 & 0.9 \\
\hline Others & 74 & 33.0 \\
\hline
\end{tabular}

and 132 days, with an average of 12.71 days $(\mathrm{SD}=$ 21.46).

\section{Discussion}

The sociodemographic data was similar to another study, in which puerperal women with premature birth had a mean age of 20 to 29 years, a steady partner, up to eight years of study and did not engage in paying job, in addition a significant association with the maternal schooling and occupation to prematurity variable. The lower the schooling, the greater the chances of prematurity. Therefore, these women tend to constitute a social group in a disadvantage of material resources and social support and, likewise, unpaid occupation. 12

Also, with regards to maternal age, in another study was found that adolescent mothers are more likely to have preterm children and have low 5- minute Apgar scores compared to adult women. ${ }^{17}$ Another research, complementing the previous one, found significance when relating women over 35 years of age and prematurity. 18

However, it is not known if age is an independent risk factor or if it is mistaken for chronic illnesses and sociodemographic factors, since advanced age increases the chancesof chronic illnesses and complications during pregnancy. However, in the current study, the average age was 28 , thus, not in the extremities of age. 19

When comparing number of births, in this study, there was a greater number, eight multiparous women, which is different from a similar study that found more primiparous women. 20

To determine gestational age, weight is normally used as a neonatal outcome factor, when considering the preterm newborn is due to the difficulty of determining the Gestational Age (GA), but it is a 
consensus to perform an ultrasound before the $20^{\text {th }}$ gestational week as a best analysis. However, in this study, the methods most used to determine the GA were the date of the last menstruation and Capurro, performed by the pediatricians. ${ }^{1}$ However, in this research, it was possible to determine GA by the first trimester using the ultrasound.

In a study that analyzed hospital births of a predetermined city, in a period of three years, significance was shown when comparing less than six prenatal consultations and prematurity. However, in our research, the average was six consultations, corresponding to the recommendation of at least this many consultations and beginning the prenatal care in the first trimester, corroborating with what is found in the literature. $5-21$

At times, it is important to observe that not only the number of consultations, but the quality of the prenatal care is essential, since a correlation between the qualityin the prenatal consultation and prematurity was found, evidencing that puerperal women with premature children had lower quality in the prenatal consultation, demonstrating the need for rigorous observation and quality in this service. 22

A study with exposed and unexposed pregnant women to tobacco, had evidenced that active and passive smoking women are at higher risk of premature childbirth, when compared to non-smoking women, as well as obtaining greater chances of having children with low weight. Although the biological mechanism is not yet clear, nicotine is known to cause vasoconstriction, altering the integrity of the amniotic membranes. Moreover, on low weight, the interaction is of tobacco, influencing in the placental hypoxia, harming the exchange of nutrients. ${ }^{23}$ However, in this study, there was no prevalence of actively-smoking women.

A study with pregnant women in Tanzania found that the predisposing factors for alcohol use during the gestation are the use of alcohol prior to the gestation, having a partner or relatives who drink, working with drinks and having previously experienced complications. ${ }^{24}$ Another study points out that alcohol abuse during the gestation is harmful for both the mother and the fetus, because alcohol crosses the placental barrier, potentially having teratogenic effects. 25 However, once again, the studied women, in their majority, did not take alcohol.

The fact that there were complications during the gestation is significant for prematurity, preeclampsia is the most evident, similar to this study and, also, showing significance with the studied outcome. 12
Concerning the use of corticoids in premature childbirth, it became evident that the protocol of the studied institution recommended two doses of the corticoid Betamethasone, or four doses of Dexamethasone, and the average of the doses was inferior to the recommended. 26

In accordance with another study, the use of corticoids in late preterm newborns reduced the need for respiratory support in the first 72 hours, as well as reducing the use of surfactants, resuscitation and prolonged stays in the nursery.27 In another research, another gestational age group was evidenced, complementing the previous study that showed that corticoids diminish hospital mortality and morbidity rates, and supports their administration in patients from 23 to 34 gestational weeks. 28

When analyzing the causes for hospitalization, pre-eclampsia was the most noted. Another research also found more cases of this pathology, describing it as the main cause of maternal mortality in Brazil, the third in the world, and it being $10 \%$ or more in Brazil and affecting $2 \%$ to $8 \%$ of the gestations worldwide. ${ }^{2}$ A study evidenced that more than half of the double gestations were premature, and $100 \%$ of the cases were when the gestation was triple or more. ${ }^{1}$ However, in our study, single gestations were prevalent.

When investigating the neonatal outcomes, greater frequency of prematurity was noted in newborns with the worst Apgar scores at the fifth minute and with low birth weight. However, in relation to the sex, no significant statistical difference was found. ${ }^{19}$ In this study, the average Apgar score was appropriate, however, the average weight was low.

In another research, C-sections presented a greater ratio of premature childbirth, although with the weighing the risks in continuing the gestation against those of premature birth, pre-eclampsia being the most common cause of planned C-sections, corroborating with a study that presented prevalence of C-sections and women with pre-eclampsia, as described. 19

Prematurity doubled the risk of hospitalization during the neonatal period and found an association with neonatal mortality, showing that prematurity is related to mortality and neonatal morbidity. The prevalence of hospitalization was 10 times greater in preterms when compared to full term newborns, corroborating once again with a study's finding that proved newborns spent an average of 12.71 days hospitalized. 29

It was observed that knowing the profile of pregnant women affected by premature childbirth in a 
maternity and the respective neonatal outcomes, relating to sociodemographic characteristics, obstetric history, pregnancy and current childbirth and neonatal data, are relevant, for it allows us to trace strategies to minimize the occurrence of serious events. Thus, the research becomes relevant for stimulating public healthcare policies that aim to diminish maternal-fetal intercurrence, guaranteeing adequate care, focusing on promoting health and the preventing sequelae.

This study presented a limitation in the absence of some information in the medical records, additional studies are being recommended in order to approach such a wide theme. Knowing and understanding premature childbirth and all its repercussions on the woman and newborn is important to improve care in the entire health-illness process.

\section{References}

1. Tuon RA, Ambrosano GMB, Silva SMCV, Pereira AC Impacto do monitoramento telefônico de gestantes na prevalência da prematuridade e análise dos fatores de risco associados em Piracicaba, São Paulo, Brasil. Cad Saúde Pública. 2016; 32 (7): 1-16.

2. Pereira SSM, Oliveira MNJ, Koller JMRC, Miranda FCA, Ribeiro IP, Oliveira ADS. Perfil de gestantes acometidas de parto prematuro em uma maternidade pública. Rev Pesq Cuid Fundam. 2018; 10 (3): 758-63.

3. Silva PLN, Costa AA, Farias HMT, Rocha LMF, Oliveira MA, Damasceno RF. Evitabilidade da mortalidade infantil na região de saúde de Janaúba / Monte Azul, Minas Gerais, Brasil. J Health Biol Sci. 2018; 6 (1): 35-41.

4. Lansky S, Friche AAL, Silva AAM, Campos D, Bittencourt SDA, Carvalho ML, Frias PG, Cavalcante RS, Cunha AJLA. Pesquisa nascer do Brasil: perfil da mortalidade neonatal e avaliação da assistência à gestante e ao recémnascido. Cad Saúde Pública. 2014; 30 (Supl. 1): 192-207.

5. Guimarães EAA, Vieira CS, Nunes FDD, Januário GC, Oliveira VC, Tibúrcio JD. Prevalência e fatores associados à prematuridade em Divinópolis, Minas Gerais, 2008-2011 análise do Sistema de Informações sobre Nascidos Vivos. Epidemiol Serv Saúde. 2017; 26 (1): 91-8.

6. Silva IO, Aredes ND, Bicalho MB, Delácio NC, Mazzo LD. Fonseca LM. Cartilha sobre o prematuro como tecnologia educacional para família: estudo quase experimental. Acta Paul Enferm. 2018; 31 (4): 334-41.

7. Demitto MO, Gravena AAF, Dell'agnolo CM, Antunes MB, Pelloso SM. Gestação de alto risco e fatores associados ao óbito neonatal. Rev Esc Enferm USP. 2017; 51 (e03208): 18

8. Tabile PM, Teixeira RM, Toso G, Matras RC, Fuhrmann IM, Pires MC, Assmann LL. Características dos partos prétermo em hospital de ensino do interior do Sul do Brasil análise de 6 anos. Rev AMRIGS. 2016; 60 (3): 168-72.

9. Santos NAAC, Costa COM, Amaral MTR, Vieira GO, Bacelar EB, Almeida AHV. Gravidez na adolescência: análise de fatores de risco para baixo peso, prematuridade cesariana. Ciênc Saúde Coletiva. 2014; 19 (3): 719-26.

\section{Acknowledgments}

We would like to thank Pedro Montoro Françozo for translating this article.

\section{Author's contribution}

Silva MM participated in all the stages. Brito ALS and Souto REM carried out the sampling. Vasconcelos IA participated in the sampling and discussion. Rocha RP reviewed the literature. Esteche CMGC performed the statistical analysis and results. Damasceno AKC and Moraes JL participated in the discussion. Saraiva MRB participated of the results and discussion. All authors approved the final version of this manuscript.

10. Canhaço EE, Bergamo AM, Lippi UG, Lopes RGC Resultados perinatais em gestantes acima de 40 anos comparados aos das demais gestações. Einstein. 2015; 13 (1): 58-64

11. Buendgens BB, Teles JM, Gonçalves AC, Bonilha ALL. Características maternas na ocorrência da prematuridade tardia. Rev Enferm UFPE online. 2017; 11 (Supl. 7): $2897-$ 906

12. Gonzaga ICA, Santos SLD, Silva ARV, Campelo V. Atenção pré-natal e fatores de risco associados à prematuridade e baixo peso ao nascer em capital do nordeste brasileiro. Ciênc Saúde Coletiva. 2016; 21 (6): 1965-74.

13. Marconi MA, Lakatos EM. Fundamento de Metodologia Científica. 7 ed. São Paulo: Atlas; 2010.

14. Polit DF, Beck CT. Fundamentos de Pesquisa em Enfermagem: avaliação de evidências para a prática de enfermagem. 7 ed. Porto Alegre: Artmed; 2011.

15. Ulysses FD. Introdução à bioestatística para simples mortais. São Paulo: Negócio Editora; 1999.

16. Harris PA, Taylor R, Thielke R, Payne J, Gonzalez N, Conde JG. Research electronic data capture (REDCap) - A metadata-driven methodology and workflow process for providing translational research informatics support. J Biomed Inform. 2009; 42 (2): 377-81.

17. Egbe TO, Omeichu A, Halle-ekane GE, Tchente CN, Egbe EN, Oury JF. Prevalence and outcome of teenage hospital births at the buea health district, South West Region, Cameroon. Reprod Health. 2015; 12 (118): 1-10.

18. Alves NCC, Feitorsa KMA, MEndes MES, Caminha MFC Complicações na gestação em mulheres com idade maior ou igual a 35 anos. Rev Gaúcha Enferm. 2017; 38 (4): 1-8.

19. Oliveira LL, Gonçalves AC, Costa JSD, Bonilha ALL. Fatores maternos e neonatais relacionados à prematuridade. Rev Esc Enferm USP. 2016; 50 (3): 382-9.

20. Junior ARF, Albuquerque RAS, Aragão SR, Rodrigues MENG. Perfil Epidemiológico de mães e recém-nascidos prematuros. Rev Enferm Contemp. 2018; 7 (1): 6-12. 
21. Brasil. Ministério da Saúde. Atenção ao pré-natal de baixo risco. Brasília, DF; 2012.

22. Melo EC, Oliveira RR, Mathias TAF. Fatores associados à qualidade do pré-natal: uma abordagem ao nascimento prematuro. Rev Esc Enferm USP. 2015; 49 (4): 540-9.

23. Ribot B, Isern R, Herna'ndez-marti'nez C, Canals J, Aranda $\mathrm{N}$, Arija V. Impacto del tabaquismo, la exposicio'n pasiva al tabaco y el dejar de fumar sobre la salud del recién nacido. MedClin (Barc). 2014; 143 (2): 57-63.

24. Melo M, Kibusi SM, Moshi F, Nyundo A, Ntwenya JE, Mpondo BCT. Prevalence and Factors Influencing Alcohol Use in Pregnancy among Women Attending Antenatal Care in Dodoma Region, Tanzania: A Cross-Sectional Study. J Pregnancy. 2018; 2018 (8580318): 1-7.

25. Baptista FH, Rocha KBB, Martinelli JL, Avó LRS, Ferreira RA, Germano CMR, Melo DG. Prevalência e fatores associados ao consumo de álcool durante a gravidez. Rev Bras Saúde Matern Infant. 2017; 17 (2): 281-9.

26. Garcia CAO, Júnior J FS, Paiva JP, Feitosa FEL. Maternidade Escola Assis Chateaubriand- Protoloco Clínico de Trabalho de Parto Prematuro. [acesso 26 nov 2018]. Disponível em: http://www.ebserh.gov.br/documents/214336/1109086/PRO.OBS.029++REV1+TRABAL HO+DE+PARTO+PREMATURO.pdf/d4014821-e7bb462f-925a- 6ac2830055b9

Received on February 15, 2019

Final version presented on August 6, 2020

Approved on September 8, 2021
27. Gyamfi-bannerman C, Thom EA, Blackwell SC, Tita AT, Reddy UM, Saade GR, Rouse DJ, Mckenna DS, Clark EA, Thorp JMJ, Chien EK, Peaceman AM, Gibbs RS, Swamy GK, Norton ME, Casey BM, Caritis SN, Tolosa JE, Sorokin Y, Vandorsten JP, Jain L; NICHD Maternal-Fetal Medicine Units Network. Betamethasone for Women at Risk for Late Preterm Delivery. New Engl J Med. 2016; 374 (14): 1311 20

28. Travers CP, Clark RH, Spitzer AR, Das A, Garite TJ, Carlo WA. Exposure to any antenatal corticosteroids and outcomes in preterm infants by gestational age: prospective cohort study. BMJ. 2017; 356 (j1039): 1-7.

29. Quaresma ME, Almeida AC, Méio MDB, Lopes JMA, Peixoto MVM. Fatores associados a internação durante o período neonatal. J Pediatr. 2018; 94 (4): 390-8. 